\title{
INFLUENCE OF ECOLOGICAL AND INTEGRATED MANAGEMENT OF FARMING ON BIODIVERSITY OF BASIC EPIGEIC GROUP
}

\author{
Jana PORHAJAŠOVÁ*, Jaroslav NOSKOVIČ, Mária BABOŠOVÁ, Terézia ČERYOVÁ, Eva CANDRÁKOVÁ \\ Slovak University of Agriculture in Nitra, Slovak Republic
}

\begin{abstract}
The aim of this experimental study was to evaluate the influence of the different types of farming on the occurrence of basic epigeic groups. The experiment was located on the locality of Experimental bases of SUA in Nitra. The results of collections of biological material obtained in the year 2012 during the growing season (April to October) and within the framework of the integrated and ecological type of farming were evaluated. There we used collection method by ground traps, which have been exposed within three crops: Medicago sativa, Triticum aestivum and Pisum sativum. The obtained epigeic groups were evaluated: dominance, identity of communities by Jaccard, degree of diversity and homeostasis of agro-ecosystems. There were obtained 7,934 ex of epigeic animals' components from which in the integrated type of farming there were 3,416 ex, and 4,518 ex in favour of organic type of farming. The obtained individuals were in 18 epigeic groups out of which in the integrated type 15 epigeic groups and in the organic type 18 epigeic groups were determinated. There were 15 epigeic groups identical for both types of farming. The frequency in crops in integrated type of farming was as follows: Medicago sativa 922 ex, Triticum aestivum 1333 ex and Pisum sativum 1161 ex, and in the ecological type of farming as follows: Medicago sativa 1131 ex, Triticum aestivum 1722 ex and Pisum sativum 1165 ex. As dominant occurring epigeic groups, there were Coleoptera, Acarina and Collembola. The presence of other epigeic groups recorded lower representation at the level of recedental or subrecedental representation; they were e.g. Formicoidea, Chilopoda, Isopoda, Diplopoda, Dermaptera, etc.. We also calculated similarity value of communities within the compared types of farming; it has reached the value of $83.33 \%$. The value of diversity in the context of the integrated system of farming was 0.6744 and in the context of the organic system of farming was 0.7172 . Specified calculated values in terms of impact of conditions and homeostasis of environment confirmed ecological farming as a better suited option because the present zoofauna reacts sensitively e.g. on the used insecticides and also the realized cultivation of the soil.
\end{abstract}

Keywords: biodiversity, ecological farming, epigeic groups, integrated farming, Coleoptera

Zooedaphon is an important component of the biocenosis, it points to the burden of agroecosystems by contaminants, it is an important bioindicator of environment, its high abundance and diversity contributes to maintaining the natural balance and circulation of the mater and energy. Strongly disturbed environment is depleted from this biocenosis element. To the above mentioned also related the presence or the absence of the observed epigeic groups, which sensitively reacts to climate, habitat and anthropogenic factors (Losos et al., 1984; Porhajašová et al., 2005). Among the most important and the most determinative factors that determinate the occurrence of epigeic groups belong humidity, temperature, shading, type of vegetation, the nature of the soil substrate, sufficiency of food and mutual competition (Boháč, 2005; Thiele, 1977; Campbell et al., 2006; Porhajašová et al., 2013). Authors Schweiger et al. (2005), Hendrickx et al. (2007), Fazekašová et al. (2011), Baranová et al. (2013) added that biodiversity of epigeic groups in agroecosystems in addition to these factors also depends on crop rotation, intensive management, neighbouring crops, as well as on other communities present in the agroecosystems. In addition to the above mentioned factors a dominant influence in agroecosystems is played by anthropogenic factors, such as extensive application of fertilizers, pesticides, intensive tillage, which results in the reduction of the presence of epigeic groups. It is important to maintain the habitats of these species because the ecological landscape stability increases with increasing ecosystem and species diversity
(Porhajašová et al., 2008; Lacko-Bartošová et al., 2005). It can be concluded that the occurrence of the epigeic groups is significantly influenced by vegetation structure of unity in the various agrotechnical interventions and inputs to soil (Petřvalský et al., 2007). The fact is that biodiversity of agroecosystems has declined compared with natural ecosystems in recent years. Intensive farming has been one of the main sources of biological simplification of the environment. During the development of agriculture many species have adapted with uniformity and extensive use of land (Schweiger et al., 2005; Hendrickx et al., 2007; Baranová et al., 2013).

At present, in the agricultural practices various forms of farming are applied, some are close to the nature and respect environmental laws. The current agricultural practices in Europe prefer organic, conventional and ecologically oriented agriculture. Many authors, such as Doring and Kromp (2003), Purtauf et al. (2005) are interested in how different management practices affect the spatial structure of epigeic groups. Šustek (2004) states that the abundance of epigeic groups is strongly influenced by the intensity and methods of farming because the present communities are exposed to the field by dramatic change in living conditions and the exposure decimates environmental conditions several times a year. Armstrong (1995) believes that between organic and conventional types of farming there are significant differences, for example: the use of different methods for liquidation of weeds, application of other types of fertilizers, another rotation of crops etc., which have 
resulted in a threat to the existing zoofauna. It is stated that the above mentioned factors significantly affect the diversity and abundance of the presence of epigeic groups. Many authors are of the opinion that the presence of epigeic groups has a unique position in the soil because they participate in decomposition processes, act as an important live component of the soil in pedogenesis and development of soil properties and contribute to stabilization, including the maintenance of soil fertility (Vician et al., 2007; Pospišil and Ondrejčíková, 2008).

The aim of this work was to evaluate the influence of different types of farming (ecological and integrated farming) on occurrence of principle epigeic groups in the years 2012 on the locality of Nitra-Dolná Malanta.

\section{Material and methods}

The experiment was carried out at the locality Nitra-Dolná Malanta, the experimental station of the Slovak University of Agriculture in Nitra, in the year 2012. The experimental site belongs to warm and moderate arid climatic region in the South-western Slovakia. The long term average precipitation is $561 \mathrm{~mm}$, for the growing season $327 \mathrm{~mm}$, altitude of $173 \mathrm{~m}$. Average air temperature is $9.7^{\circ} \mathrm{C}$. The main soil type is orthic luvisol with medium supply of available $\mathrm{P}$, high content of available $\mathrm{K}$ and good content of available $\mathrm{Mg}$ and $\mathrm{pH} 6.4$ in an average. The sampling of epigeic groups/material was realized during the vegetation period from April to October by soil traps with two replications, fulfilled with $4 \%$ solution of formaldehyde. Soil traps were controlled and renewed in month intervals.

Soil traps were exposed in organic and integrated farming system in the following crops: Medicago sativa, Triticum aestivum and Pisum sativum. The following indicators - dominance, identity of species by Jaccard (IJ), the degree of diversity according to Shannon-Weavera (d), modified by Schwerdtfeger (1978) and homeostasis of agro-ecosystems were evaluated.

\section{Results and discussion}

In the two systems of farming, integrated and organic, at the locality of Nitra-Dolná Malanta there were collected 7,934 ex epigeic of animal components, belonging to 18 taxonomic groups, of which 17 were a part of a group of invertebrates and only one group was vertebrate. Comparing both types of farming, there were found 15 epigeic groups in an integrated and 18 epigeic groups in favour of organic farming type. Based on the results presented in Table 1 and Table 2 it can be assessed that the number of collected individuals corresponds to the used methodology of the collection. In view of the abundance of individuals, better conditions were reported in organic farming, which grained 4,518 ex compared with the integrated farming: 3,416 ex. The tables also present the dominance of present groups, such as the dominant groups i. e. presence over $5 \%$ are epigeic groups Coleoptera, Acarina and Collembola. Below $5 \%$ i.e. on the level of subrecent representation

Table 1 Abundance and dominance of epigeic groups, in the year 2012, on the locality Nitra-Dolná Malanta

\begin{tabular}{|c|c|c|c|c|c|c|c|c|c|c|c|c|}
\hline \multirow{3}{*}{$\begin{array}{r}\begin{array}{r}\text { Integrated } \\
\text { farming }\end{array} \\
\text { Epigeic groups }\end{array}$} & \multicolumn{4}{|c|}{ Medicago sativa } & \multicolumn{4}{|c|}{ Triticum aestivum } & \multicolumn{4}{|c|}{ Pisum sativum } \\
\hline & \multirow{2}{*}{$\begin{array}{r}1 . \\
\text { rep. }\end{array}$} & \multirow{2}{*}{$\begin{array}{c}2 . \\
\text { rep. }\end{array}$} & \multicolumn{2}{|c|}{ Total } & \multirow{2}{*}{$\begin{array}{c}1 . \\
\text { rep }\end{array}$} & \multirow{2}{*}{$\begin{array}{c}2 . \\
\text { rep. }\end{array}$} & \multicolumn{2}{|c|}{ Total } & \multirow{2}{*}{$\begin{array}{c}1 . \\
\text { rep. }\end{array}$} & \multirow{2}{*}{$\begin{array}{c}2 . \\
\text { rep. }\end{array}$} & \multicolumn{2}{|c|}{ Total } \\
\hline & & & ind. & $\%$ & & & ind. & $\%$ & & & ind. & $\%$ \\
\hline Acarina & 105 & 199 & 304 & 32.97 & 195 & 255 & 450 & 33.76 & 294 & 105 & 399 & 34.36 \\
\hline Araneida & 29 & 41 & 70 & 7.59 & 34 & 29 & 63 & 4.73 & 26 & 62 & 88 & 7.58 \\
\hline Coleoptera & 134 & 133 & 267 & 28.95 & 319 & 276 & 595 & 44.64 & 314 & 202 & 516 & 44.45 \\
\hline Collembola & 37 & 127 & 164 & 17.78 & 39 & 53 & 92 & 6.91 & 3 & 47 & 50 & 4.32 \\
\hline Dermaptera & 4 & 4 & 8 & 0.86 & 2 & 2 & 4 & 0.30 & 3 & - & 3 & 0.26 \\
\hline Diplopoda & 1 & 11 & 12 & 1.31 & 3 & 12 & 15 & 1.12 & 10 & 7 & 17 & 1.47 \\
\hline Diptera & 4 & 3 & 7 & 0.76 & 7 & 1 & 8 & 0.60 & 2 & 3 & 5 & 0.43 \\
\hline Formicoidea & 11 & 12 & 23 & 2.49 & 3 & - & 3 & 0.22 & 2 & 2 & 4 & 0.34 \\
\hline Hymenoptera & 5 & 1 & 6 & 0.65 & 4 & - & 4 & 0.30 & - & - & - & - \\
\hline Chilopoda & 2 & 2 & 4 & 0.43 & - & - & - & - & 1 & 1 & 2 & 0.17 \\
\hline Isopoda & 4 & 7 & 11 & 1.19 & 5 & 1 & 6 & 0.45 & 3 & 3 & 6 & 0.52 \\
\hline Larvae & 13 & 2 & 15 & 1.64 & 8 & 23 & 31 & 2.32 & 3 & - & 3 & 0.26 \\
\hline Lumbricidae & 3 & - & 3 & 0.33 & - & 2 & 2 & 0.15 & 1 & 1 & 2 & 0.17 \\
\hline Muridae & - & - & - & - & - & 2 & 2 & 0.15 & 1 & - & 1 & 0.08 \\
\hline Opilionida & 9 & 19 & 28 & 3.05 & 22 & 36 & 58 & 4.35 & 38 & 27 & 65 & 5.59 \\
\hline Total & 361 & 561 & 922 & 100.00 & 641 & 692 & 1,333 & 100.00 & 701 & 460 & 1,161 & 100.00 \\
\hline
\end{tabular}


Table 2 Abundance and dominance of epigeic groups, in the year 2012, on the locality Nitra-Dolná Malanta

\begin{tabular}{|c|c|c|c|c|c|c|c|c|c|c|c|c|}
\hline \multirow{3}{*}{$\begin{array}{r}\begin{array}{r}\text { Ecological } \\
\text { farming }\end{array} \\
\text { Epigeic groups }\end{array}$} & \multicolumn{4}{|c|}{ Medicago sativa } & \multicolumn{4}{|c|}{ Triticum aestivum } & \multicolumn{4}{|c|}{ Pisum sativum } \\
\hline & \multirow{2}{*}{$\begin{array}{r}1 . \\
\text { rep. }\end{array}$} & \multirow{2}{*}{$\begin{array}{c}2 . \\
\text { rep. }\end{array}$} & \multicolumn{2}{|c|}{ Total } & \multirow{2}{*}{$\begin{array}{c}1 . \\
\text { rep }\end{array}$} & \multirow{2}{*}{$\begin{array}{c}2 . \\
\text { rep. }\end{array}$} & \multicolumn{2}{|c|}{ Total } & \multirow{2}{*}{$\begin{array}{c}1 . \\
\text { rep. }\end{array}$} & \multirow{2}{*}{$\begin{array}{c}2 . \\
\text { rep. }\end{array}$} & \multicolumn{2}{|c|}{ Total } \\
\hline & & & ind. & $\%$ & & & ind. & $\%$ & & & ind. & $\%$ \\
\hline Acarina & 177 & 250 & 427 & 37.75 & 230 & 200 & 430 & 24.97 & 160 & 234 & 394 & 23.66 \\
\hline Araneida & 20 & 23 & 43 & 3.80 & 42 & 54 & 96 & 5.57 & 63 & 46 & 109 & 6.55 \\
\hline Coleoptera & 122 & 145 & 267 & 23.62 & 419 & 364 & 783 & 45.47 & 443 & 435 & 878 & 52.73 \\
\hline Collembola & 135 & 65 & 200 & 17.68 & 85 & 85 & 170 & 9.87 & 11 & 58 & 69 & 4.14 \\
\hline Dermaptera & 7 & 3 & 10 & 0.88 & 6 & 2 & 8 & 0.46 & 10 & 5 & 15 & 0.90 \\
\hline Diplopoda & 8 & 12 & 20 & 1.78 & 12 & 3 & 15 & 0.87 & 7 & 13 & 20 & 1.20 \\
\hline Diptera & 4 & 1 & 5 & 0.44 & 5 & 3 & 8 & 0.46 & 7 & 3 & 10 & 0.60 \\
\hline Formicoidea & 54 & 20 & 74 & 6.55 & 9 & 20 & 29 & 1.69 & 4 & 5 & 9 & 0.54 \\
\hline Heteroptera & 2 & - & 2 & 0.17 & 2 & 2 & 4 & 0.23 & - & 4 & 4 & 0.24 \\
\hline Hymenoptera & - & 2 & 2 & 0.17 & 1 & 3 & 4 & 0.23 & 2 & 1 & 3 & 0.18 \\
\hline Chilopoda & - & 1 & 1 & 0.09 & 3 & 3 & 6 & 0.35 & 3 & 4 & 7 & 0.42 \\
\hline Isopoda & 1 & 4 & 5 & 0.44 & 3 & 2 & 5 & 0.29 & 3 & 4 & 7 & 0.42 \\
\hline Larvae & 1 & 4 & 5 & 0.44 & - & 20 & 20 & 1.16 & 6 & 10 & 16 & 0.96 \\
\hline Lumbricidae & - & 1 & 1 & 0.09 & 1 & 1 & 2 & 0.12 & - & 1 & 1 & 0.06 \\
\hline Muridae & - & - & - & - & - & - & - & - & 1 & - & 1 & 0.06 \\
\hline Opilionida & 25 & 41 & 66 & 5.83 & 69 & 73 & 142 & 8.26 & 31 & 43 & 74 & 4.45 \\
\hline Saltatoria & 1 & 2 & 3 & 0.27 & - & - & - & - & 3 & - & 3 & 0.18 \\
\hline Siphonaptera & - & - & - & - & - & - & - & - & 45 & - & 45 & 2.71 \\
\hline Total & 557 & 574 & 1,131 & 100.00 & 887 & 835 & 1,722 & 100.00 & 799 & 866 & 1,665 & 100.00 \\
\hline
\end{tabular}

was recorded in groups of Araneida, Opilionida, Diplopoda, Formicoidea, Chilopoda, Saltatoria, Dermaptera, etc. Despite their lower representation, these groups contribute to biodiversity of agroecosystem and reflect its stability. A similar view was also expressed by Lenoir and Lennartsson (2010) who report the epigeic groups with the higher abundance in agroecosystem of Araneida, Formicoidea and Coleoptera, which according to Peterková (2004) due to th high abundance and diversity significantly affect the maintenance of the natural balance and substance cycle and flow of energy in ecosystems. Holecová et al. (2003) state that the dominant groups are epigeic ant communities which significantly affect each biocenosis. Their activities accelerate the decomposition of plant residues, aerate the soil and improve soil structure and quality which is confirmed by our findings.

From the point of view of the occurrence, the major role is not played only by the system of farming but also the crop in which the soil traps were exposed. As the most appropriate crop we can evaluate winter wheat (tab. 1 and 2) which created the best topical and trophical conditions. There are also species whose biotopes are in the soil (moisture content of the substrate), or many of them are heliophobe and prefer shading (Petřvalský et al., 2007). The frequency in the integrated type of farming was: Medicago sativa 922 ex, Triticum aestivum 1,333 ex and Pisum sativum 1,161 ex. The frequency in the organic farming was: Medicago sativa 1,131 ex, Triticum aestivum 1,722 ex and Pisum sativum 1,165 ex. From the presented results the crop of Triticum aestivum can be evaluated as appropriate based on the occurrence and abundance of epigeic groups. In terms of comparison of both systems of farming based on the obtained results we can evaluate the organic farming as more appropriate.

When calculating the similarity/identity of communities by Jaccard (IJ) occurring in both types of farming, faunistic similarity of $83.33 \%$ was calculated. The calculated value is relatively high and demonstrates the suitability of the monitored biotopes in comparison with biotopes that are strongly influenced by anthropic activities whose calculated value was about 45\% (Porhajašová et al., 2008b).

The degree of diversity by Shannon-Weaver (d), which is based on species richness, is often used for the characteristics of populations. The degree of diversity is higher when the number of species in the sample is bigger and total number of individuals is divided among more taxa, but this is not confirmed in our case. The evidence of this is relatively low values of diversity. The value of diversity within integrated farming was 0.6744 and it confirmed the type of farming as more appropriate, value of diversity was 0.7172. These results correspond with Porhajašová (2011) who calculated relatively low values in agroecosystems significantly affected by human activity. 


\section{Acknowledgements}

This paper was supported by VEGA project no. 1/0513/12 "Research of sustainable agroecosystems for migration of climate change, production of bioproducts, improvement of human nutritional and health parameters", VEGA project

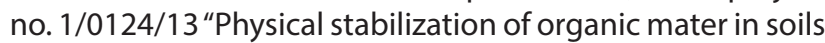
of different ecosystems" and VEGA project no. 1/0816/11 "Production process of field crops at different tillage systems, application of fertilizers and plant residues to maintenance and increasing of soil fertility".

\section{References}

ARMSTRONG, G. 1995. Carabid beetle (Coleoptera: Carabidae) diversity and abundance in organic potatoes and conventionally grown seed potatoes in the north of Scotland. In: Pedobiologia, vol. 39, 1995, no. 2, p. 231-237. ISSN 0031-4056.

BARANOVÁ, B. - FAZEKAŠOVÁ, D. - JÁSZAY, T. - MANKO, P. 2013. Ground beetle (Coleoptera: Carabidae) community of arable land with different crops. In: Folia faunistica Slovaca, vol. 18, 2013, no. 1, p. 21-29. ISSN 1336-4529.

BOHÁČ, J. 2005. Brouci - střevlíkovití. In: Kučera, T. Červená kniha biotopů. [online]. 2005. [2011-07-30]. Dostupné na internete: http://www.usbe.cas.cz/cervenakniha/texty/tax_skupiny/.

CAMPBELL, N. A. - REECE, J. B. 2006. Biologie. Computer Press, a.s., 2006. p. 633-676. ISBN 80-251-1178-4.

DORING, T. F. - KROMP, B. 2003. Which carabid species benefit from organic agriculture? A review of comparative studies in winter cereals from Germany and Switzerland. In: Agriculture, Ecosystems and Environment, vol. 98, 2003, no. 1-3, p. 153-161. ISSN 0167-8809. HENDRICKX, F. - MAELFAIT, J. P. - VAN WINGERDEN, W. a i. 2007. How landscape structure, land use intensity and habitat diversity affect components of total arthropod diversity in agricultural landscapes. In: Journal of Applied Ecology, 2007. no. 44. p. 340-351.

HOLECOVÁ, M. - LUKÁŠ, J. - HARAKAL'OVÁ, E. 2003. Mravce (Hymenoptera, Formicidae) dubovo-hrabových lesov $v$ okolí Bratislavy (JZ Slovensko). In: Folia faunis. Slovaca, vol. 8, 2003, p. 63-69. ISSN 1335-7522.

LACKO-BARTOŠOVÁ, M. - CAGÁŇ, L.. - ČUBOŇ, J. et al. 2005. Udržatel'né a ekologické polnohospodárstvo. Nitra : SPU, 2005. 571 s. ISBN 80-8069-556-3.

LENOIR, L. - LENNARTSSON, T. 2010. Effects of timing of grazing on arthropod communities in semi-natural grasslands. In: Journal of Insect Science, vol. 10, 2010, p. 33-42. ISSN 1536-2442.

LOSOS, B. - GULIČKA, J. - LELLÁK, J. - PELIKÁN, J. 1984. Ekologie živočichů. Praha : SPN, 1. vydanie, 1984, $300 \mathrm{~s}$.

PETERKOVÁ, V. 2004. Dynamika výskytu bystruškovitých v alternatívnom spôsobe pestovania plodín. In: Acta Fac. Paed. Univ. Tyrnaviensis. Ser. B, no. 8, 2004, s. 11-13. ISBN 80-8082-013-9. PETŘVALSKÝ, V. - PORHAJAŠOVÁ, J. - URMINSKÁ, J. - ONDRIŠÍK, P. MACÁK, M. 2007. Výskyt základných epigeických skupín v závislosti od množstva organickej hmoty. In: Acta Facultatis Ecologiae, roč. 15, 2007, s. 15-19. ISSN 1336-300X.

PORHAJAŠOVÁ, J. - PETŘVALSKÝ, V. - URMINSKÁ, J. - POSPIŠIL, R. 2005. Vplyv množstva organickej hmoty $v$ pôde na výskyt epigeónu a populácií bystruškovitých (Carabidae, Coleoptera). In: Acta horticulturae et regiotecturae, roč. 8, 2005, č. 2, s. 42-46. ISSN 1335-2563.
PORHAJAŠOVÁ, J. - PETŘVALSKÝ, V. - MACÁK, M. - URMINSKÁ, J. - ONDRIŠÍK, P. 2008a. Occurence of species family Carabidae (Coleoptera) independence on the input of organic matter into soil. In: Journal of Central European Agriculture, vol. 9, 2008a, no. 3, p. 557-566. ISSN 1332-9049.

PORHAJAŠOVÁ, J. - PETŘVALSKÝ, V. - ŠUSTEK, Z. - URMINSKÁ, J. - ONDRIŠ́KK, P. - NOSKOVIČ, J. 2008b. Long-termed changes in ground beetle (Coleoptera: Carabidae) assembleges in a field treated by organic fertilizers. In: Biologia-Section Zoology, vol. 63, 2008b, no. 6, p. 1184-1195. ISSN 1336-9563.

PORHAJAŠOVÁ, J. 2011. Vplyv aplikácie organických hnojív na priestorovú štruktúru bezstavovcov s dôrazom na čelad' Carabidae. In: Habilitačná práca. $133 \mathrm{~s}$.

PORHAJAŠOVÁ, J. - ŠUSTEK, Z. - NOSKOVIČ, J. - BABOŠOVÁ, M. 2013. The effect of application of organic fertilizers on the dynamics of occurence of Carabid species (Carabidae: Coleoptera). In: Jour. Centr. Europ. Agricul, vol. 14, 2013, no. 2, p. 251-272. ISSN 1332-9049.

POSPIŚIL, R. - ONDREJČíKOVÁ, Z. 2008. Vplyv biokalu na produkciu a kvalitu slnečnice ročnej (Helianthus annus L.). In: Naše pole, 2008, č. 3, s. 18-19. ISSN 1335-2466.

PURTAUF, T. - ROSCHEWITZ, I. - DAUBER, J. - THIES, C. 2005. Landscape context of organic and conventional farms: Influence on carabid beetle diversity. In: Agriculture, Ecosystems and Environment, vol. 108, 2005, no. 2, p. 165-174. ISSN 0167-8809.

SCHWEIGER, O. - MAELFAIT, J.P. - VAN WINGERDEN, W. a i. 2005. Quantifiying the impact of environmental factors on arthropod communities in agricultural landscapes across organizational levels and spatial scales. In: Journal of Applied Ecology, no. 42, 2005, p. 1129-1139.

SCHWERDTFEGER, F. 1978. Lehrbuch der Tierőkologie. Verlag Paul Parey - Hamburg und Berlin, 1978, 384 p. ISBN 3-490-07718-0.

ŠUSTEK, Z. 2004. Characteristics of humidity requirements and relation to vegetation cover of selected Central-European Carabids (Coleoptera, Carabidae). In: Geobiocenotické spisy, Svazek no. 9, Brno: MZLU, 2004, p. 210-213.

THIELE, L.U. 1977. Carabid beetles in Their environments. A study on Habitat Selection by Adaptations in Physiology and Behaviour. Springer-Verlag-Berlin - Heidelberg - New York, 1977, p. 331-352. VICIAN, V. - STAŠIOV, S. - KOČÍK, K. - HAZUCHOVÁ, L. 2007. Štruktúra chrobákov (Carabidae, Coleoptera) na rôzne obhospodarovaných pol'nohospodárskych plochách. In: Zborník z konferencie: „Vplyvy foriem obhospodarovania polnohospodárskej krajiny na základné zložky agroekosystémov vo vztahu k optimalizácii využivania krajiny". Vyd. Čižmárová-Partner, 2007, s. 67-77. ISBN 978-80-89183-35-7.

Contact address:

doc. Ing. Jana Porhajašová, PhD., Slovak University of Agriculture in Nitra, Faculty of Agrobiology and Food Resources, Department of Environmental Sciences and Zoology, Tr. Andreja Hlinku 2, 949 76, Slovak Republic, Jana.Porhajasova@uniag.sk 